\title{
Jaringan Pengelolaan Zakat Untuk Pertumbuhan Industri Keuangan Non Bank Syariah
}

\author{
Ernawati \\ Fakultas Ekonomi dan Bisnis Universitas Halu Oleo, Indonesia \\ Email korenpondensi: erna_unhalu@yahoo.com
}

\begin{abstract}
Sharia non bank financial industry (IKNB) still low share of the conventional IKNB. The one of strategy to accelerating growth in sharia IKNB is through the management of zakah, infaq, sadaqah and awqaf (ZISWAF). This paper aims to explore the zakah management model for the growth of sharia IKNB. The secondary data were obtained through reports, information and zakat regulation. The analytical method used is descriptive and transaction cost approach. The results show that the growth of IKNBS can be accelerated with an active role of IKNBS in the ZISWAF management as a Unit Pengumpul Zakah (UPZ), besides partnership with Lembaga Amil Zakah (LAZ ). Partnership Model will minimize control and information cost of ZISWAF management. Lack of human resource and technological are the problems management zakah by sharia IKNB.
\end{abstract}

Kata Kunci: Management, ZISWAF, Partnership

Saran sitasi: Ernawati, E. (2018). Jaringan Pengelolaan Zakat untuk Pertumbuhan Industri Keuangan Non Bank Syariah. Jurnal Ilmiah Ekonomi Islam, 4(03), 168-176. doi:http://dx.doi.org/10.29040/jiei.v4i03.310

DOI: http://dx.doi.org/10.29040/jiei.v4i03.310

\section{Pendahuluan}

Industri keuangan memiliki peran yang penting dalam transaksi ekonomi dan non ekonomi. Pada perkembangan lebih lanjut, industri keuangan tidak hanya dapat bertumpu pada model perbankan yang memiliki batasan cakupan jasa yang ditawarkan. Variasi dan perkembangan berbagai transaksi keuangan memunculkan kebutuhan akan pentingnya lembaga non bank. Di Indonesia seiring perkembangan industri keuangan syariah, industri keuangan non bank syariah juga mengalami ekspansi. Baik aspek jumlah, maupun jenisnya. Berdasarkan data Otoritas Jasa Keuangan (2016), jenis industri keuangan non bank (IKNB) berbasis syariah terdiri dari lembaga asuransi, lembaga pembiayaan, pegadaian, lembaga keuangan mikro syariah, lembaga pembiayaan ekspor dan lembaga penjamin simpanan serta modal ventura.

Share aset IKNB syariah terhadap IKNB konvensional sekitar 4 persen. Secara individu, pada posisi Desember 2015, share perusahaan asuransi sebesar 5,74 persen, perusahaan pembiayaan 5,25 persen, perusahaan penjaminan 5,48 persen, pegadaian syariah 9,56 persen, serta pembiayaan ekspor syariah 13,06 persen. Adapun komposisi IKNB syariah disajikan sebagaimana Tabel 1 yang menunjukkan bahwa perusahaaan asuransi merupakan pemilik share terbesar dalam industri keuangan non bank syariah, baik dari aspek jumlah perusahaan maupun aset; disusul oleh perusahaan pembiayaan. 
Sementara share terendah untuk porsi aset dimiliki oleh lembaga keuangan mikro syariah.

Rendahnya share IKNB syariah berimplikasi masih terbatasnya kapasitas ekspansi industri keuangan non bank syariah. Keterbatasan tersebut dapat bersumber dari sisi supply (penawaran) maupun demand (permintaan). Penawaran dapat menciptakan permintaan (supply created demand), dapat pula sebaliknya. Namun kedua sisi ini perlu diletakkan secara proposional agar saling mendukung antara satu dengan lainnya. Artinya, dalam upaya peningkatan peran mayarakat dalam industri keuangan syariah diperlukan perbaikan sistem di tingkat lembaga keuangan non bank syariah itu sendiri.

Berbagai upaya perlu dilakukan dalam rangka peningkatan kapasitas keuangan IKNBS, baik dari aspek sumber keuangan maupun aspek pembiayaan. Salah satu potensi terbesar dalam pengelolaan keuangan syariah yaitu dana zakat, termasuk infaq, sedekah dan waqaf (ZISWAF). Zakat merupakan kewajiban seorang muslim, dan merupakan rukun Islam ke-4. Zakat akan berkembang seiring dengan perkembangan ekonomi. Sehingga semakin berkembang perekonomian (karenanya pendapatan) maka akan semakin tinggi pula potensi zakat. Namun pengelolaan zakat selama ini masih jauh dari potensi yang ada, yang jika merujuk pada hasil penelitian Firdaus, dkk (2012) jumlahnya mencapai 3,4 persen dari Produk Domestik Bruto (PDB). Kekuatan organisasi pengelola zakat ternyata belum mampu mengoptimalkan penerimaan zakat, yang hanya mencapai 1 persen dari potensi yang ada. Organisasi pengelola zakat di Indonesia sebanyak 38.013 organisasi yang terdiri dari Badan Amil Zakat Nasional (BAZNAS) 1 unit, Lembaga Amil Zakat Nasional (LAZNAS) 18 unit, Lembaga Amil Zakat (LAZ) propinsi/kabupaten 47 unit, unit pengumpul zakat (UPZ) 8.680 unit, dan sisanya adalah Badan Amil Zakat Baerah (BAZDA) baik yang berkedudukan di tingkat propinsi, kabupaten, kecamatan, maupun kelurahan (Juwaini, 2011). Dengan demikian permasalahan lemahnya pemberdayaan masyarakat juga ditentukan oleh lemahnya jaringan LAZ dalam pengumpulan zakat. Penelitian Ernawati (2016) menunjukkan bahwa seluruh LAZNAS memiliki target pemberdayaan baik mustahik perorangan maupun kelompok.

Pada sisi lain, jaringan pengelolaan ZISWAF yang ada masih 'kering' dari keterlibatan industri keuangan non bank syariah. Pengelolaan zakat selama ini hanya terlayani pada lembaga keuangan mikro Baitul Mal wat Tamwil (BMT). BMT mengalokasikan dana zakat, infak dan sedekah dalam bentuk non komersil (qardrul hasan) guna pengembangan usaha kaum duafa (Sumarni, 2018). Namun ruang gerak lembaga ini masih sangat terbatas dan berskala kecil, sehingga belum mampu menjangkau potensi zakat yang cukup besar. Padahal zakat dapat merupakan sumber keuangan yang aman bagi IKNBS, sebab memiliki 'biaya dana' yang rendah namun sekaligus dapat memperoleh bagian zakat sebagai amil (pengumpul). Sehingga pengelolaan dana ZISWAF oleh

Tabel 1 Jumlah Perusahaan dan Aset Industri Keuangan Syariah di Indonesia Tahun 2015

\begin{tabular}{|c|c|c|c|c|}
\hline Jenis Industri & $\begin{array}{c}\text { Jumlah Full } \\
\text { Syariah }\end{array}$ & $\begin{array}{c}\text { Jumlah } \\
\text { UUS }\end{array}$ & $\begin{array}{c}\text { Aset } \\
\text { (Miliar Rp) }\end{array}$ & Share \\
\hline Perusahaan Asuransi Syariah & 8 & 45 & 26.519 & 40,87 \\
\hline Perusahaan Pembiayaan Syariah & 3 & 37 & 22.350 & 34,45 \\
\hline Perusahaan Modal Ventura Syariah & 4 & 2 & 481 & 0,74 \\
\hline Perusahaan Penjaminan Syariah & 2 & 2 & 618 & 0,95 \\
\hline PT Pegadaian (Persero) & 0 & 1 & 3.749 & 5,78 \\
\hline Lembaga Pembiayaan Ekspor & 0 & 1 & 11.137 & 17,17 \\
\hline Indonesia (LPEI) & & & & \\
\hline Lembaga Keuangan Mikro Syariah & 5 & 0 & 27 & 0,04 \\
\hline Total & 22 & 88 & 64.882 & 100,00 \\
\hline
\end{tabular}

Sumber: OJK 2016, diolah 
IKNBS selain sebagai unit pengumpul zakat juga dapat mendorong pertumbuhan IKNB tersebut.

Berdasarkan hal tersebut, maka diperlukan suatu kajian mengenai model-model jaringan pengelolaan ZISWAF untuk pertumbuhan industri keuangan non bank syariah. Model tersebut dapat ditinjau dari berbagai aspek. Salah satu pendekatan yang dapat digunakan dalam penilaian model jaringan tersebut yaitu biaya transaksi. Tulisan ini mengkaji model jaringan pengelolaan ZISWAF dengan pendekatan biaya transaksi, baik biaya informasi, pengawasan maupun biaya lainnya untuk mendorong partumbuhan IKNBS di Indonesia

\section{Metode Penelitian}

Studi model jaringan pengumpulan zakat dilakukan pada lembaga amil zakat nasional (LAZ), baik dari pihak korporasi, maupun orsosmas. Sumber penelusuran UPZ/LAZ melalui publikasi Forum Zakat (FOZ) dan BAZNAS. Penelusuran juga dilakukan pada kelompok Bank Umum Syariah (BUS) dan LKMS. Jumlah LAZ yang diteliti sebanyak 13 LAZ berbasis sosial kemasyarakatan; dan seluruh UPZ/LAZ berbasis BUS serta LKMS. Pengumpulan data dilakukan melalui dokumentasi hasil publikasi kegiatan dan laporan zakat LAZ yang diperoleh melalui direktory on line masing-masing LAZ dan BUS. Pada sisi lain dilakukan pula pengumpulan data melalui studi kepustakaan dari hasil penelitian dan gagasan-gagasan terkait dengan kelembagaan zakat. Model pengelolaan ZISWAF diderivasi dari penelaahan model yang diadaptasi oleh muzakki maupun UPZ/LAZ di Indonesia. Selanjutnya dilakukan analisis alternatif model untuk pertumbuhan IKNBS dengan pendekatan transaction cost, yang terdiri dari biaya informasi, pengambilan keputuan, dan biaya pengawasan. Pengukuran transaction cost dilakukan secara kualitatif yang merujuk pada indikator 'tinggi' dan 'rendah' berdasarkan penelaahan penulis. Selanjutnya dilakukan kajian atas peluang dan tantangan model pengelolaan ZISWAF berdasarkan kepustakaan yang relevan.

\section{Hasil dan Pembahasan}

\subsection{LAZ sebagai Lembaga Pengelola Dana} Zakat

Lembaga pengelola zakat di Indonesia terdiri dari lembaga yang didirikan oleh pemerintah dan lembaga yang didirikan oleh masyarakat. Lembaga yang didirikan oleh pemerintah yang bertindak sebagai pengumpul zakat yaitu Badan Amil Zakat Nasional dan Daerah (BAZNAS dan BAZDA). Cakupan kerja BAZNAS secara nasional sementara BAZDA hanya berada pada wilayah propinsi maupun kabupaten/kota yang dibentuk oleh pemerintah daerah. Unit pengumpul zakat (UPZ) BAZNAS telah mencapai 101 unit, dan 32 diantaranya merupakan korporat, baik BUMN/BUMD maupun privat. Namun tidak semua UPZ berbadan hukum Lembaga Amil Zakat Nasional. Adapun LAZ yang telah disahkan oleh Kementrian Agama sebagai Lembaga Amil Zakat Nasional yang didirikan oleh masyarakat dan organisasi sosial disajikan sebagaimana Tabel 2.

Lembaga Amil Zakat Nasional tampaknya memiliki kekuatan yang cukup besar dari aspek jaringan. Lembaga Amil Zakat Hidayatullah, PKPU, Rumah Zakat, LAZISNU, PZU merupakan LAZNAS dengan jaringan terbesar. Jaringan ini merupakan suatu upaya LAZ untuk menjangkau muzakki potensial. Jejaring ini diperkuat oleh sistem pembayaran dana yang lebih mudah berbasis elektronik atau e-banking yang dipadukan dengan sitem manual pembayaran di konter bank, konter lembaga, maupun sistem jemput. Namun seluruh LAZ hanya menerima penyetoran pembayaran baik di bank umum baik berbentuk bank syariah maupun bank konvensional, dan tidak memiliki varian model pembayaran melalui lembaga keuangan lainnya termasuk IKNB.

Lembaga amil zakat tampaknya tidak hanya terfokus pada donasi ZISWAF namun memperluas donasi untuk dana kemanusiaan, CSR, bahkan dalam bentuk barang. Secara umum, penyaluran dana LAZ diarahkan pada bidang ekonomi, kesehatan, pendidikan, dakwah, dan sosial kemanusiaan. Program sosial kemanusiaan 


\section{Jurnal Ilmiah Ekonomi Islam, 4(03), 2018, 171}

Tabel 2 Karakteristik Lembaga Amil Zakat Indonesia

\begin{tabular}{|c|c|c|c|c|}
\hline Nama Lembaga & $\begin{array}{c}\text { Tahun } \\
\text { LAZNAS }\end{array}$ & Jenis Donasi & Jejaring & Alokasi \\
\hline $\begin{array}{l}\text { Pos Keadilan dan } \\
\text { Peduli Umat (PKPU) }\end{array}$ & 2001 & $\begin{array}{l}\text { Zakat, Infaq, Sedekah, } \\
\text { Waqaf, CSR Perusahaan, } \\
\text { Barang, Qurban, Dana } \\
\text { Bencana Kemanusiaan }\end{array}$ & 43 Kantor & $\begin{array}{l}\text { Ekonomi, pendidikan, kesehatan, } \\
\text { sosial }\end{array}$ \\
\hline Rumah Zakat (RZ) & 2003 & ZIS & $\begin{array}{l}43 \text { kantor } \\
\text { Cabang }\end{array}$ & $\begin{array}{l}\text { Ekonomi, pendidikan, kesehatan, } \\
\text { sosial }\end{array}$ \\
\hline Dompet Duafa & 2001 & $\begin{array}{l}\text { Zakat, Infaq, Sedekah, } \\
\text { Waqaf, CSR Perusahaan, } \\
\text { Kurban, Kemanusiaan, dll }\end{array}$ & 17 Cabang & $\begin{array}{l}\text { Ekonomi, pendidikan, kesehatan, } \\
\text { sosial }\end{array}$ \\
\hline $\begin{array}{l}\text { Dompet Peduli Ummat } \\
\text { Daruttauhid (DPU DT) }\end{array}$ & 2004 & ZISWAF & 15 cabang/unit & $\begin{array}{l}\text { Ekonomi, pendidikan, dakwah, } \\
\text { sosial }\end{array}$ \\
\hline Lazis Dewan Da'wah & 2002 & $\begin{array}{l}\text { ZIS dan donasi sosial } \\
\text { individu/ perusahaan }\end{array}$ & 4 Lazis daerah & Dakwah, sosial \\
\hline $\begin{array}{l}\text { Inisiatif Zakat } \\
\text { Indonesia (IZI) }\end{array}$ & 2015 & ZIS & 14 perwakilan & $\begin{array}{l}\text { Ekonomi, pendidikan, kesehatan, } \\
\text { dakwah, sosial }\end{array}$ \\
\hline $\begin{array}{l}\text { Baitul Maal } \\
\text { Hidayatullah }(\mathrm{NMH})\end{array}$ & 2015 & ZIS, kemanusiaan, CSR & $\begin{array}{l}69 \text { Unit } \\
\text { pembantu }\end{array}$ & $\begin{array}{l}\text { Ekonomi, pendidikan, dakwah, } \\
\text { sosial }\end{array}$ \\
\hline $\begin{array}{l}\text { Lazis Muhammadiah } \\
\text { (Lazis MU) }\end{array}$ & na & ZIS, sosial, kemanusiaan & n.a & $\begin{array}{l}\text { Ekonomi, pendidikan, dakwah, } \\
\text { sosial }\end{array}$ \\
\hline LAZIS NU & 2010 & ZIS, CSR, dll & $\begin{array}{l}42 \\
\text { wilayah/cabang }\end{array}$ & $\begin{array}{l}\text { Ekonomi, pendidikan, dakwah, } \\
\text { sosial }\end{array}$ \\
\hline $\begin{array}{l}\text { Pusat Zakat Ummat } \\
(\mathrm{PZU})\end{array}$ & 2001 & ZISWAF & $\begin{array}{l}34 \\
\text { perwakilan/unit }\end{array}$ & $\begin{array}{l}\text { pendidikan, kesehatan,dakwah, } \\
\text { sosial, dan ekonomi }\end{array}$ \\
\hline Yayasan Nurul Hayat & 2015 & ZISWAF & $\begin{array}{l}19 \text { kantor } \\
\text { perwakilan }\end{array}$ & $\begin{array}{l}\text { Kesehatan, pendidikan, ekonomi } \\
\text { sosial, dakwah }\end{array}$ \\
\hline $\begin{array}{l}\text { PPPA Yayasan Darul } \\
\text { Qur'an }\end{array}$ & n.a & $\begin{array}{l}\text { Sedekah dan lainnya } \\
\text { (kurban, aqiqah, dsb) }\end{array}$ & 8 Kantor Cabang & Pendidikan, Dakwah, Sosial \\
\hline $\begin{array}{l}\text { Yayasan Dana Sosial } \\
\text { Al Falah (YDSF) }\end{array}$ & 2001 & ZIS dan lainnya & $\begin{array}{l}7 \text { cabang/ } \\
\text { jaringan }\end{array}$ & $\begin{array}{l}\text { Pendidikan, Kesehatan, Dakwah, } \\
\text { Sosial, Ekonomi }\end{array}$ \\
\hline
\end{tabular}

Sumber: Direktori Online Masing-masing LAZ (diakses September 2016)

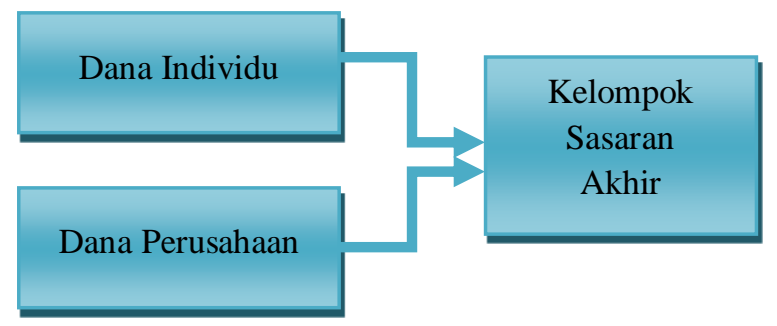

Sumber: Hasil Analisis Penelitian

Gambar 1 Model Pertama Pengumpulan ZISWAF di Indonesia

dapat berbentuk tanggap darurat (bencana alam, daerah konflik, dst). Adapun bantuan kesehatan yang dilakukan LAZ diarahkan pada bantuan pengobatan dan penyediaan sarana/prasarana kesehatan. Sementara dana pendidikan berbentuk beasiswa, pelatihan pendidik, maupun sarana dan prasarana sekolah. Beberapa program dakwah yang dilakukan LAZ yaitu pelatihan dai serta pengadaan sarana dan prasarana ibadah. Sementara alokasi anggaran dalam bidang ekonomi secara umum dalam bentuk bantuan modal, pendampingan usaha, dana bergulir dan peningkatan skill kewirausahaan.

\subsection{Model Jaringan Pengelolaan Dana Zakat}

Model rantai pengumpulan dan alokasi dana ZISWAF/donasi di Indonesia setidaknya ada 5 (lima) model; Model Pertama (Gambar 1) Individu maupun perusahaan mengalokasikan secara langsung pada kelompok sasaran. Model ini dianggap oleh individu maupun perusahaan lebih efektif. Bagi perusahaan, model langsung ini sangat disesuaikan dengan nilai-nilai perusahaan Selanjutnya, pada Model Kedua (Gambar 2) jaringan pengelolaan zakat menunjukkan bahwa baik individu maupun perusahaan menyerahkan donasi yang dimiliki kepada LAZ baik sebagian maupun seluruhnya yang kemudian disalurkan kepada kelompok sasaran. Model ini diadopsi secara umum oleh Bank Umum Syariah di Indonesia. Masyarakat yang mengadopsi model ini memiliki manfaat tersendiri dari 
penyaluran zakat, selain lebih terorganisir, zakat yang dibayarkan juga diakui sebagai pengurang pajak berdasarkan Peraturan Direktur Jenderal Pajak Nomor PER-11/PJ/2018.

Pada Model Ketiga (Gambar 3) individu dan atau perusahaan melakukan pembayaran zakat pada UPZ yang telah ditunjuk oleh LAZ. Dana yang dimiliki sebagian atau seluruhnya diteruskankan pada LAZ maupun dialokasikan secara langsung. BAZNAS menggunakan model jaringan ini dengan UPZ yang berasal dari pemerintah maupun privat. Begitupun halnya dengan BAZDA yang memiliki UPZ sampai dengan tingkat kelurahan bahkan di rumah ibadah/ tingkat mesjid.

Model jaringan yang melibatkan lembaga keuangan mikro syariah lebih besar disajikan pada Model Keempat sebagaimana Gambar 4. Pada Model Keempat, individu maupun perusahaan penyalurkan zakat melalui lembaga keuangan (bank umum) yang kemudian menya- lurkan kepada LAZ yang selanjutnya dialokasikan kepada kelompok sasaran. Model ini salah satunya diadopsi oleh Bank Muamalat Indonesia, yang tidak hanya menyalurkan dananya kepada LAZ namun juga kepada BMT. Pada Model Keempat ini tidak ada relasi antara IKNBS dan LAZ (BAZNAS)

Selanjutnya pada Model Kelima (Gambar 5) merupakan model integrasi antara institusi zakat dan lembaga keuangan mikro. Model Kelima menunjukkan bahwa IKNBS (khususnya lembaga keuangan mikro) dapat berperan sebagai UPZ dan atau LAZ yang secara langsung dapat menyalurkan pendanaan pada masyarakat miskin (asnaf) produktif. Berbeda halnya dengan Model Keempat, yang secara umum masih terdapat hubungan kemitraan antara pembayar zakat (dalam hal ini perbankan syariah misalnya) dengan IKNBS, pada Model Kelima IKNBS tidak memiliki hubungan kemitraan dengan

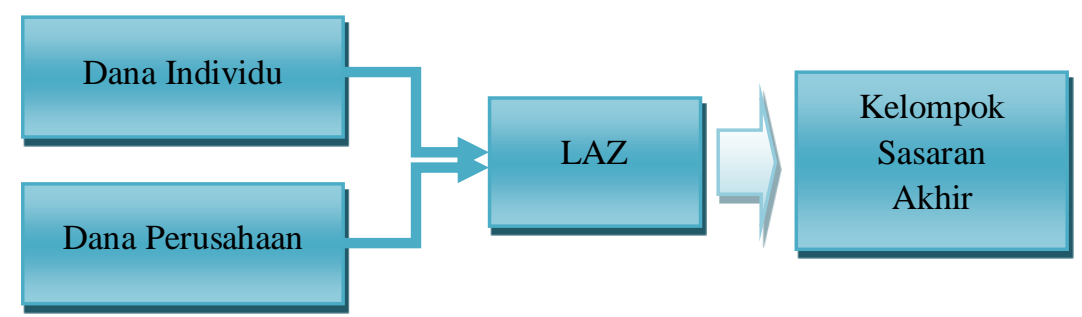

Sumber: Hasil Analisis Penelitian

Gambar 2 Model Kedua Pengumpulan ZISWAF di Indonesia
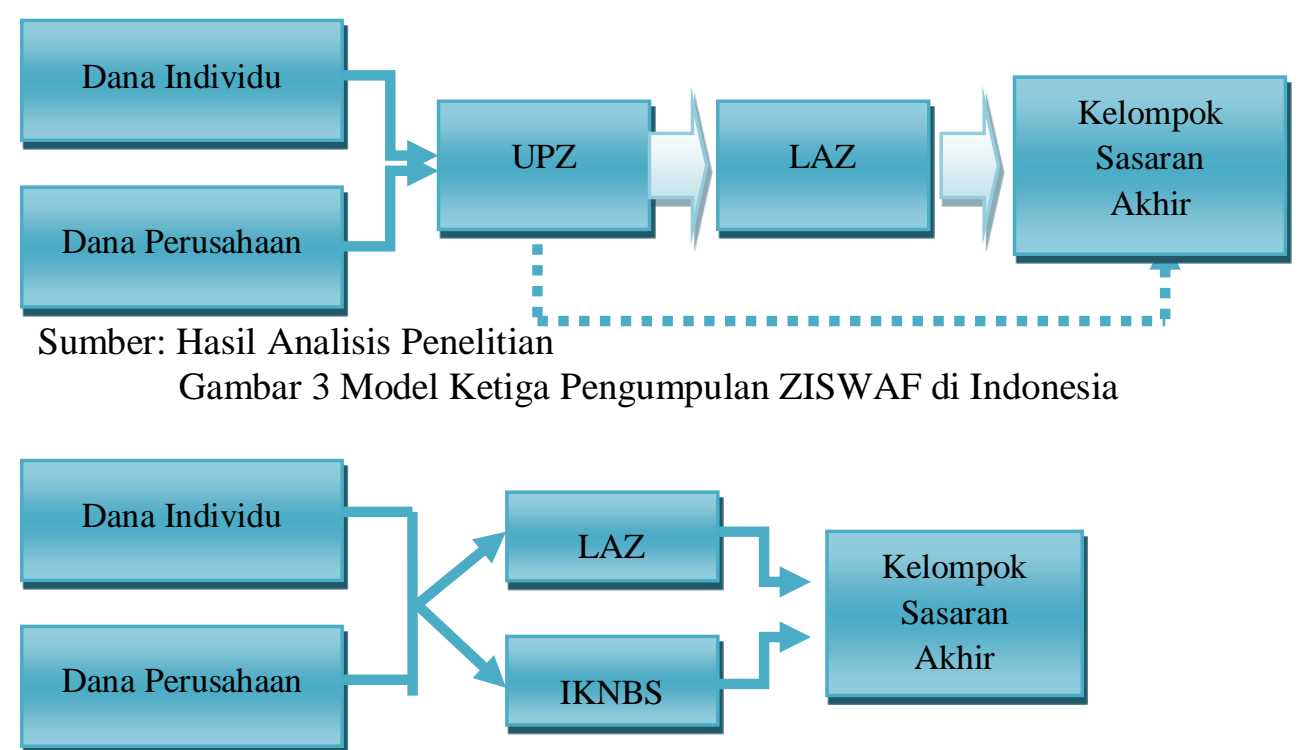

Sumber: Hasil Analisis Penelitian

Gambar 4 Model Keempat Pengumpulan ZISWAF di Indonesia 
pembayar zakatnya. Model ini secara khusus telah diadopsi oleh lembaga keuangan mikro syariah BMT Indonesia yang meskipun bukan merupakan UPZ dan LAZ namun melakukan layanan penerimaan ZISWAF yang selanjutnya dialokasikan pada pembiayaan produktif bagi masyarakat. Lembaga non bank syariah lain seperti asuransi, pegadaian, pembiayaan, dst tampaknya belum memiliki peran signifikan pada kelima model yang telah dipaparkan sebelumnya. Oleh karena itu diperlukan modifykasi model jaringan dalam rangka peningkatan peran yang sebesar-besarnya dari berbagai lembaga non bank syariah. Model modifikasi ini sebagaimana disajikan pada Gambar 6 .

Pada Gambar 6 IKNBS bertindak langsung sebagai UPZ dari LAZ yang ada. Dana yang tidak sesuai dengan jasa layanan UPZ IKNBS akan disalurkan ke pada LAZ afiliasinya. Begitu- pun pula dana yang ada pada LAZ akan dialokasikan kepada IKNBS sesuai bidang usahanya masing-masing. Sebagai contoh, layanan pendidikan dan kesehatan dapat dikelola oleh jasa asuransi syariah, sementara layanan modal usaha dapat dikelola oleh LKMS, Lembaga Pembiayaan, dan Pegadaian. Tujuan akhir dari model ini yaitu berdaya secara ekonomi, kesehatan dan pendidikan. Meskipun alokasi dana tidak berorientasi bagi hasil, namun model ini tentu saja berorientasi jangka panjang, sehingga dapat merubah mustahik menjadi muzakki. Industri Keuangan Non Bank Syariah dapat mengambil manfaat pengelolaan dana sebagai amil zakat baik dari muzakki lama maupun dari muzakki baru (yang sebelumnya mustahik).

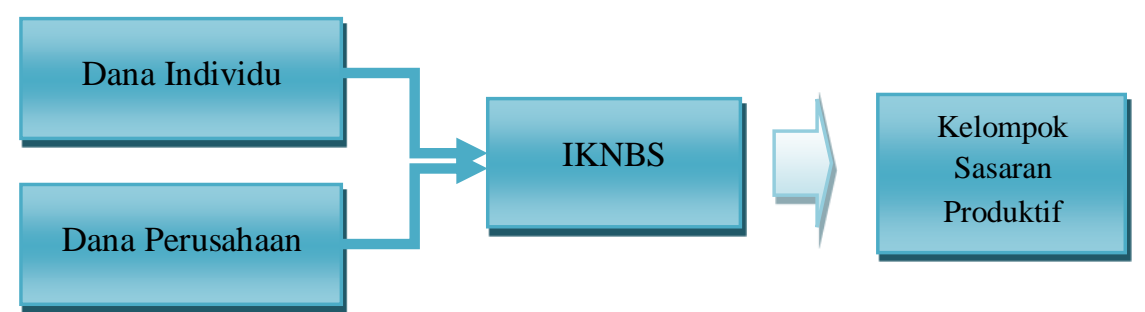

Sumber: Hasil Analisis Penelitian

Gambar 5 Model Kelima Pengumpulan ZISWAF di Indonesia

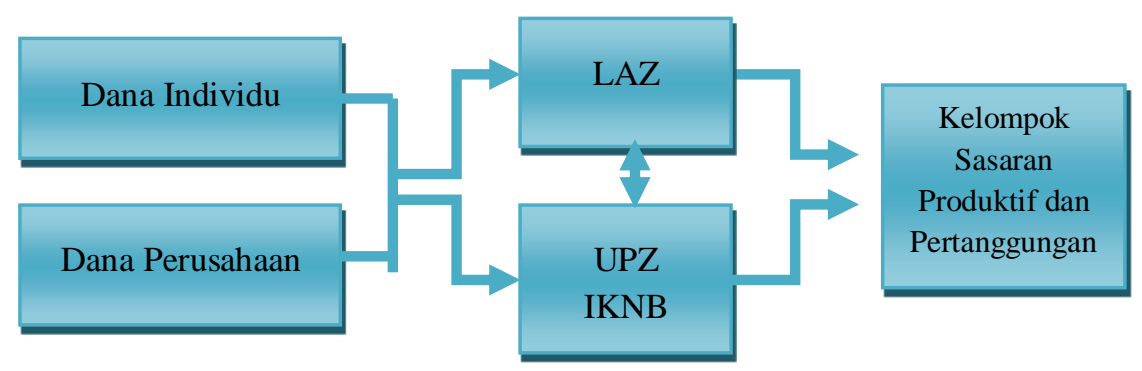

Sumber: Hasil Analisis Penelitian

Gambar 6 Model Modifikasi Pengumpulan ZISWAF

Tabel 7 Sasaran Utama Model Jaringan Pengumpulan ZIS

\begin{tabular}{|c|c|c|}
\hline Model & Uraian & Alasan Penggunaan Model \\
\hline 1 & Model Langsung & Persaudaraan \\
\hline 2 & Model BAZNAS & Pengeloaan ZIS sebagai kewajiban negara \\
\hline 3 & Model Agency & $\begin{array}{l}\text { Koordinasi antar lembaga untuk mencapai muzakki } \\
\text { potensial }\end{array}$ \\
\hline 4 & Model Mandiri & $\begin{array}{l}\text { Mengisi keterbatasan negara dalam mengelola ZIS, CSR, } \\
\text { bantuan kemanusiaan, Kebutuhan Tanggap darurat, dsb }\end{array}$ \\
\hline 5 & Mode & Mengisi keterbatasan negara dalam mengelola ZIS produktif \\
\hline 6 & Model Kemitraan & Sinergitas pengelolaan ZIS produktif \\
\hline
\end{tabular}

Sumber: Hasil Analisis Peneliti 
Secara ringkas, penggunaan dan alasan/ kondisi penggunaan dari keenam model jaringan pengelolaan zakat disajikan sebagaimana Tabel 7. Model Pertama sampai Model Keempat yang disajikan bukanlah trade off antara satu dengan lainnya, sebab model-model tersebut diperlukan dalam rangka penyaluran zakat fitrah dan upayaupaya tanggap darurat lainnya. Model Pertama merupakan model persaudaraan, yang memang dianjurkan oleh Islam untuk mengutamakan sedekah pada 'keluarga'. Model ini juga dianjurkan bagi perusahaan untuk memberikan sumbangan nyata bagi lingkungan sekitar perusahaan. Sementara Model Kedua merupakan model BAZNAZ/BAZDA yang menganggap bahwa zakat merupakan kewajiban negara untuk melakukan pungutan. Adapun Model Ketiga, lebih fleksibel dibanding Model Kedua yang melibatkan unit pengumpul (agency) diluar pemerintahan guna mencapai muzakki potensial.

Selanjutnya pada Model Keempat, yang merupakan model mandiri dapat dilakukan dalam kondisi upaya-upaya tanggap darurat. Sebab mobilisasi massa dan pendanaan dapat lebih efektif jika melibatkan partisipasi masyarakat. Namun untuk Model Kelima dan Keenam dapat dilakukan trade off antara satu dengan lainnya, yaitu bahwa pemerintah dapat memilih salah satu model yang dinggap dapat mendorong efektifitas pengelolaan zakat produktif, sekaligus mendorong IKNBS untuk lebih berkembang.

Pemilihan Model Integrasi (Model Kelima) atau Model Kemitraan (Model Keenam) dapat mendorong keterlibatan aktif IKNBS, bukan hanya sebagai obyek namun juga sebagai subyek pengelola dana ZISWAF. Pilihan atas kedua model ini dapat dilakukakn melalui pendekatan biaya transaksi. Biaya transaksi digunakan untuk mengukur efesien tidaknya desain kelembagaan, semakin tinggi biaya transaksi maka desain kelembagaan semakin tidak efesien, dan sebaliknya. Biaya transaksi merupakan perpindahan barang, jasa, informasi, pengetahuan dll, dari satu tempat (komunitas) ke tempat (komunitas) lain; atau pemindahan barang dari produsen ke konsumen, atau pemindahan barang dari satu individu ke individu yang lain yang terdiri dari: biaya transaksi pasar, biaya transaksi manajerial, dan biaya transaksi politis (Furubotn \& Richter, 2010). Biaya transaksi pasar merupakan seluruh biaya yang dikeluarkan agar barang/jasa bisa sampai ke pasar: meliputi biaya persiapan kontrak (biaya pencarian/pengadaan informasi), biaya pembuatan kontrak (biaya bargaining, negosiasi dan pembuatan keputusan), biaya monitoring dan penegakan kontrak.

Pada model jaringan pengelolaan zakat yang mampu mendorong IKNBS, beberapa biaya transaksi yang harus dipertimbangkan yaitu: biaya informasi, biaya pembuatan kontrak, dan biaya pengawasan. Biaya informasi pengelolaan zakat terdiri dari biaya kelayakan mustahik, termasuk di dalamnya biaya overlapping mustahik. Biaya pembuatan kontrak terdiri dari biaya penilaian sampai pengambilan keputuan IKNBS untuk mendanai mustahik. Sementara biaya pengawasan terdiri dari biaya koordinasi antara lembaga dan pertanggungjawaban UPZ IKNBS.

Perbandingan biaya antara Model Integrasi dan Kemitraan disajikan sebagaimana Tabel 8. Pada Model Integrasi, biaya informasi sangat tinggi karena minimnya koordinasi antara lembaga zakat. Sehingga LAZ IKNBS akan melakukan survey kelayakan mustahik dengan waktu dan biaya yang cukup besar. Sebab IKNBS bukanlah lembaga zakat yang memiliki basis data mustahik. Berbeda halnya dengan Model Kemitraan, yang berjejaring dengan LAZ, biaya ini dapat diminimalkan, sebab LAZ yang telah ada memiliki basis data mustahik. Terlebih lagi bahwa dengan berjejaring, overlapping pendanaan dapat lebih diminimalkan.

Selanjutnya untuk biaya pembuatan keputusan harus diakui bahwa pada Model Integrasi, keputusan akan lebih cepat, dikarenakan LAZ dan IKNBS berada pada institusi yang sama. Sebaliknya dengan Model Kemitraan. Namun biaya ini dapat diminimalkan dengan adanya pelimpahan prosedur administrasi pembuatan keputusan di wilayah UPZ IKNBS 
Jurnal Ilmiah Ekonomi Islam, 4(03), 2018, 175

Tabel 8 Biaya Transaksi Model Integrasi dan Model Kemitraan

\begin{tabular}{lcc}
\hline \multicolumn{1}{c}{ Jenis Biaya } & Model Integrasi & Model Kemitraan \\
\hline Biaya Informasi & Tinggi & Rendah \\
Biaya Pembuatan Keputusan & Rendah & Tinggi \\
Biaya Pengawasan & Tinggi & Rendah \\
\hline
\end{tabular}

Sumber: Hasil Analisis Penelitian

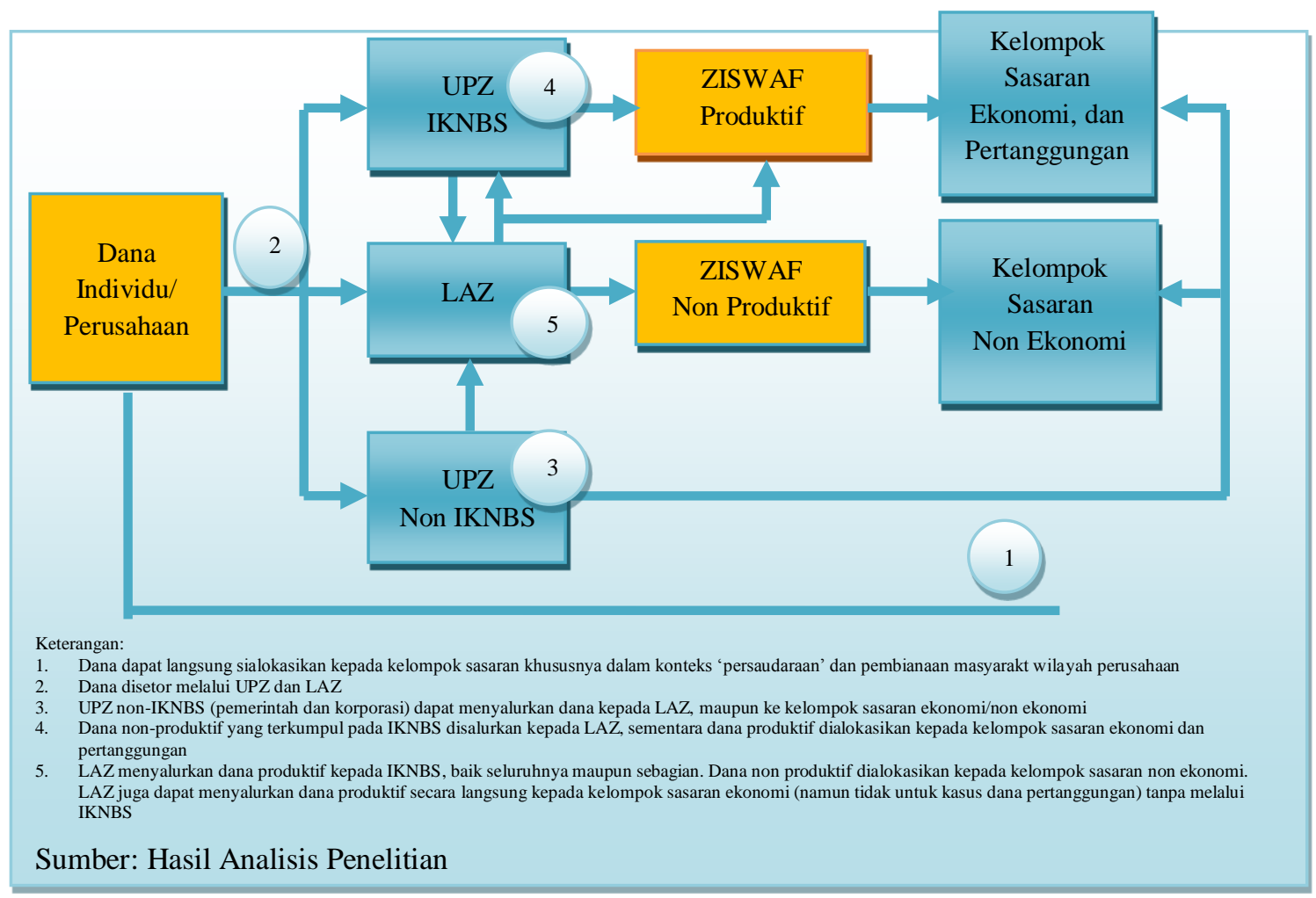

Gambar 7 Full Model Pengelolaan Zakat

Pada Model Integrasi, BAZNAS sebagai lembaga koordinasi ZISWAF akan menghadapi koordinasi yang lebih rumit dibanding pada Model Kemitraan. Pengawasan Model Kemitraan akan dilakukan secara berjenjang, yaitu UPZ IKNBS akan bertanggungjawab kepada LAZ yang menaunginya, sekaligus bertanggungjawab kepada Otoritas Jasa Keuangan sebagai lembaga pengawas. Sehingga tampak bahwa IKNBS bagi LAZ merupakan agency untuk zakat produktif dan dana pertanggungan (kesehatan dan pendidikan).

Berdasarkan model pengelolaan zakat Model Pertama sampai Keempat dan Model Keenam, maka dapat disusun full model pengelolaan zakkat (termasuk infak, sedekah dan wakaf serta dana sosial lain) sebagaimana diajikan pada Gambar 7.
Keterbatasan sumberdaya juga merupakan masalah dalam optimalisasi jaringan penerimaan zakat. Sumberdaya pengelolaan zakat terdiri dari: teknologi dan kualitas amil zakat. Kualitas amil zakat bukan hanya dalam pengumpulan ZISWAF, namun juga dalam pengambilan keputusan alokasinya. Perlu dilakukan standariasi kopetensi dan sertifikai amil zakat (Forum Zakat, 2012). Adaptasi teknologi pengelolaan dana zakat perlu terkoneksi dengan berbagai institusi zakat dan UPZ IKNBS. Sehingga terjalin database utuh dari keseluruhan sistem pengelolaan zakat Indonesia.

\subsection{Peluang dan Tantangan Kemitraan Industri Keuangan Non Bank Syariah dan Lembaga Amil Zakat dalam Pengelolaan Dana ZISWAF}

Peluang dan tantangan pengelolaan zakat oleh IKNBS dapat ditinjau dari aspek regulasi, kelembagaan, dan sumber daya manusia dan 
teknologi. Pada sisi regulasi, Peraturan Menteri Agama No 52 tahun 2014 telah menyiratkan kebolehan mendayagunakan dana zakat untuk usaha produktif sengan syarat sebagaimana pasal 33: (a) apabila kebutuhan dasar mustahik telah terpenuhi; (b) memenuhi ketentuan syariah; (c) menghasilkan nilai tambah ekonomi untuk mustahik; dan (d) mustahik berdomisili di wilayah kerja lembaga pengelola zakat. Selanjutnya pada pasal 34 dinyatakan bahwa pendayagunaan zakat untuk usaha produktif dapat dilakukan paling sedikit memenuhi ketentuan: (a) penerima manfaat merupakan perorangan atau kelompok yang memenuhi ketentuan mustahik; dan (b) mendapat pemdampingan LAZ diwilayah domisili mustahik. Namun tantangan yang dihadapi terkait optimalisasi dana zakat yaitu belum adanya regulasi 'pemaksaan' zakat oleh negara, sebagaimana 'pemaksaan' pajak. Selanjutnya pada sisi kelembagaan, IKNBS memiliki berbagai jenis layanan yang sesuai dengan kebutuhan mustahik, misalnya asuransi syariah untuk layanan kesehatan dan pendidikan mustahik; pembiayaan syariah untuk pembiayaan produktif usaha mustahik; LKMS untuk bantuan modal mustahik dan sebagaimnya. Namun tantangan yang ada memang belum terdapatnya regulasi yang mengatur secara khusus pengelolaan zakat pada IKNBS.

\section{Kesimpulan}

Pertumbuhan industri keuangan non bank (IKNB) syariah dapat didorong melalui peran aktif IKNBS dalam pengelolaan dana ZIS dengan memposisikan IKNBS sebagai unit pengumpul zakat (UPZ), sekaligus bermitra dengan LAZ. Pada sisi lain, IKNBS memiliki berbagai bentuk lembaga yang dapat secara cepat merespon layanan ZIS, seperti: asuransi syariah untuk alokasi dana pendidikan dan kesehatan mustahik; pembiayaan syariah, LKMS dan pegadaian syariah untuk layanan usaha mustahik. Mekipun dalam pengelolaan dana ZISWAF, IKNBS tidak profit oriented, IKNBS tetap dapat dapat memperoleh benefit dari status kelembagaan amil zakat, dan usaha lainnya yang tidak bertentangan dengan syariah. Pilihan model kemitraan ini memiliki beberapa tantangan yaitu: belum adanya regulasi keterlibatan IKNBS dalam pengelolaan zakat, maupun aspek minimnya sumberdaya manusia dan konektivitas teknologi pengelolaan zakat.

\section{Ucapan Terimakasih}

Terimakasih kepada Departemen Ilmu Ekonomi dan Studi Pembangunan FEB Universitas Halu Oleo, atas dukungannya hingga karya ilmiah ini diterbitkan.

\section{Daftar Pustaka}

Ernawati, E. (2016). Karakteristik program pemberdayaan mustahik oleh Lembaga Amil Zakat Nasional Di Indonesia. INFERENSI Jurnal Penelitian Sosial Keagamaan, 10(2), 309-334.

Firdaus, M., Beik, I. S., Irawan, T., \& Juanda, B. (2012). Economic estimation and determinations of Zakat potential in Indonesia. Jeddah: Islamic Research and Training Institute.

Forum Zakat. 2012. Cetak Biru Pengembangan Zakat Indonesia 2011-2025, Panduan Masa Depan Zakat Indonesia. [diunduh 2016 Maret 30]. Tersedia pada: http://www.forumzakat.org

Furubotn, E. G., \& Richter, R. (2010). nstitutions and economic theory: The contribution of the new institutional economics. University of Michigan Press.

Juwaini, A. (2011). Strategi pengembangan SDM zakat indonesia, dalam Strategi pengelolaan zakat di Indonesia. Jakarta: FOZ, hlm. 33-41.

OJK.2016. Statistik IKNBS. [diunduh 2016 Maret 25] . Tersedia pada: http://ojk.go.id

Peraturan Menteri Agama No 52 tahun 2014 Tentang Syarat dan Tata Cara Perhitungan Zakat Mal dan Zakat Fitrah Serta Pendayagunaan Zakat untuk Usaha Pproduktif

Sumarni, S. (2018). Pendistribusian Dana Zakat Infak Sedekah (ZIS) untuk Pemberdayaan Masyarakat Studi Kasus BMT Amanah Ummah Sukoharjo. Jurnal Ilmiah Ekonomi Islam, 4(02), 116-125. doi:http://dx.doi.org/10.29040/jiei.v4i2.261 
Jurnal Ilmiah Ekonomi Islam, 4(03), 2018, 177 